\title{
Integrated dementia care: A qualitative evidence synthesis of the experiences of people living with dementia, informal carers and healthcare professionals
}

\author{
Raymond Smith ", Anne Martin, Toni Wright, Sabina Hulbert, Eleni Hatzidimitriadou \\ Faculty of Medicine, Health and Social Care, Canterbury Christ Church University, North Holmes Road, Canterbury, Kent, CT1 1QU, UK
}

\section{A R T I C L E I N F O}

\section{Keywords:}

Dementia

Integrated care

Care homes

Caregivers

Healthcare professionals

Evidence synthesis

\begin{abstract}
A B S T R A C T
Background: In order to provide improved care provision, integrated care services are being developed. However, little is known about how people living with dementia, their families and healthcare professionals experience integrated care. Therefore, the purpose of this review of the qualitative literature was to examine the experiences and perceptions of integrated dementia care.

Methods: This qualitative review synthesised findings from included studies identified from a comprehensive literature search. Searches included: five electronic databases, journal handsearching, and reference list searching of relevant literature reviews and the final included studies.

Findings: Three overarching themes were identified: 1) Ways of working which facilitate the delivery of integrated dementia care; 2) Informal carers as equal partners in care provision and decision making; and 3) Challenges leading to fragmented and disjointed integrated dementia care. For integrated care to be successful, communication and collaboration between healthcare professionals, and the involvement of informal carers is needed. Multidisciplinary teams and employing case managers to coordinate care provision can improve communication and collaboration. However, distrust between healthcare professionals and a lack of a central database to access and share information often hinders the development of integrated dementia care service provision.

Conclusion: Integrated dementia care can be successful and well received by people living with dementia and their families when certain conditions are met. However, given the negative consequences fragmented and disjointed care can have on people living with dementia and their families, action is needed to further support the development of integrated dementia care services.
\end{abstract}

\section{Background}

As of 2015, approximately 46.8 million people were living with dementia worldwide, which is predicted to increase to 131.5 million by 2050. Europe and North America accounted for just under one third of the 2015 total with 15.3 million diagnoses (Prince et al., 2015). In the United Kingdom (UK) there were almost 885,000 people living with dementia as of 2019 , with 1.9 million projected to be living with the condition by 2040 (Wittenberg et al., 2019). With these increasing numbers, more people living with dementia and their informal carers will need to access various health and social care services, with integrated care an important facilitator in ensuring appropriate service delivery.

There are various definitions and concepts related to integrated care, with more than 70 terms and phrases relating to 175 definitions and concepts (Armitage et al., 2009). This lack of common terminology makes it challenging to compare and contrast experiences of integrated care, whether on a national or international level (Stein \& Rieder, 2009). Therefore, for clarity in this review when referring to integrated care, the definition provided by Shaw et al. (2011) will be used: 'Integrated care is an organising principle for care delivery with the aim of achieving improved patient care through better coordination of services provided'. This interpretation, that it is the needs of those using the service at the centre of integrated care provision, has also been adopted by the English

\footnotetext{
* Corresponding author.

E-mail addresses: Raymond.Smith@canterbury.ac.uk, RSmith.Research@aol.com (R. Smith), Anne.Martin@canterbury.ac.uk (A. Martin), Toni.Wright@ canterbury.ac.uk (T. Wright), Sabina.Hulbert@canterbury.ac.uk (S. Hulbert), Eleni.Hatzidimitriadou@canterbury.ac.uk (E. Hatzidimitriadou).
} 
government which uses it to frame its integrated care strategies (World Health Organisation [WHO], 2016). The English government views integrated care as 'person-centred coordinated care' at its core (National Voices, 2013).

\subsection{Impact of fragmented integrated dementia care}

People living with dementia and their informal carers need to access different health and social care services, often simultaneously. However, navigating and accessing these services can be challenging due to fragmentation, limited remit and inadequate cross partnership working (Peel \& Harding, 2014). The consequences of fragmented and underutilised care services are numerous, but often result in multiple and unnecessary visits from and to health and social care professionals; emergency hospital admissions; unreliable transitions through care pathways; and unreliable transfers from hospitals to a person's home (Department of Health \& Social Care, 2013). Fragmented service provision may also explain evidence showing that people living with dementia access fewer social care services than people living with other long-term conditions (Vecchio et al., 2016). It can also often lead people living with dementia to remain in hospital longer than necessary, negatively impacting on their quality of life (Kar, 2015).

Whilst some studies have shown integrated dementia care offers improved outcomes for people living with dementia and their informal carers (Wolfs et al., 2008), the evidence for its effectiveness in this population remains mixed due to the numerous types of integration that can occur and barriers to implementing integrated care models. For example, aspects of integrated care that can improve outcomes for service users can include: case management; care coordination; outreach teams for those living in rural areas; and multidisciplinary teams being involved in all aspects of patient care. Notable barriers which can inhibit integrated care include the various types of communication used by healthcare professionals and informal carers, such as telephone, internet messaging and video calling - some of which are impractical or poorly utilised, poor care continuity, and a lack of adequate funding and resources (Draper et al., 2019).

\subsection{The importance of integrated care}

That which constitutes integrated care is often described differently between people, with person-centred perspectives of what matters most to the person often being the main driver behind service delivery (Goodwin, 2016), for example: 'The patient's perspective is at the heart of any discussion about integrated care. Achieving integrated care requires those involved with planning and providing services to impose the patient's perspective as the organising principle of service delivery' (Lloyd \& Wait, 2005). A recent systematic review of the most commonly shared values of integrated care from various countries found seven common values: collaborative; co-ordinated; transparent; empowering; comprehensive; co-produced; and shared responsibility and accountability (Zonneveld et al., 2018). However, the majority of the included studies in the synthesis were from the perspectives of researchers or health professionals, with none of the participants involved in developing the seven common values being either informal carers or people (including people living with dementia) utilising services. It is therefore important to understand integrated care from their perspectives as well as healthcare professionals if the '...patient's perspective as the organising principle of service delivery' (Lloyd \& Wait, 2005) is to be accomplished.

Integrated dementia care can improve client satisfaction, increase use of appropriate community services and reduce the number of days spent in hospital (Low \& Fletcher, 2015). Integrating care was a key area for improvement in UK dementia policy documents, for example, the English National Dementia Strategy (Department of Health [DH], 2009). More recently, other European countries (e.g. Ireland, France, Italy, Denmark, and The Netherlands) have published National Dementia Strategies, with the aim of improving care services to support people living with dementia and their families. The development of integrated care services is also a priority for these countries, with both the Italian and Norwegian National Dementia Strategies reporting integrated care as a target area for improvement (Alzheimer Europe, 2017).

Frequently, models of integrated care enhance client satisfaction and perceived quality of care received (Baxter et al., 2018). However, whilst there is good evidence for the effectiveness of integrated care in older populations generally, such as a reduced need to transition into nursing home care and fewer hospital visits, the evidence for its effectiveness in those with long-term conditions and complex needs, including those living with dementia, is mixed (Ham \& Curry, 2011). Therefore, there is a need to explore why this is the case from the perspectives of those who access integrated care services, their families and the healthcare professionals delivering integrated care.

\subsection{Research question and aims}

Research has shown that integrated care can offer improved outcomes for people living with dementia and their families, however their experiences remain poorly understood and the evidence currently available has not been synthesised. Therefore, the purpose of this review of the qualitative literature was to examine the experiences and perceptions of integrated care from the perspectives of people living with dementia, informal carers and healthcare professionals. The research questions were:

1 What are the experiences of integrated dementia care from the perspectives of people living with dementia, informal carers and healthcare professionals?

2 What do people living with dementia, informal carers and healthcare professionals perceive to be good quality integrated care?

3 What are the facilitators and barriers to receiving integrated dementia care?

\section{Methods}

This review of qualitative evidence aimed to synthesise the experiences of integrated dementia care from all key stakeholders (Booth et al., 2016). The nine steps of qualitative evidence synthesis reported in Booth (2017) were followed: 1) development of clearly formulated review question; 2) scoping the literature; 3) formal identification of the relevant literature; 4) initial assessment of study reports; 5) analysis and synthesis; 6) preliminary synthesis; 7) full synthesis; 8) dissemination; 9) throughout an iterative process. These steps are not linear and review authors can move between stages as necessary.

The review was reported using the enhancing transparency in reporting the synthesis of qualitative research (ENTREQ) statement (Tong et al., 2012). This guideline consists of 21 items grouped into five main domains: introduction, methods and methodology, literature search and selection, appraisal, and synthesis of findings. The research questions and search strategy were developed using the population, interest and context (PICo) process, which is often used in qualitative literature reviews (Centre for Reviews and Dissemination [CRD], 2009).

\subsection{Inclusion criteria}

Table 1

1 Qualitative evidence exploring the experiences of integrated dementia care

2 Primary research exploring the experiences of people living with dementia, informal carers and healthcare professionals

3 Peer reviewed and grey literature

4 Published in English

5 There were no date restrictions 


\subsection{Exclusion criteria}

Table 2

1 Opinion pieces, letters, commentaries or editorials

2 Conference abstracts

3 Literature reviews

\subsection{Electronic search strategy}

The following five electronic databases were searched from their first records: MEDLINE (1948 to 6th July 2020); PsycINFO (1967 to 6th July 2020); Social Policy and Practice (SPP - 1981 to 6th July 2020); Social Science Citation Index (SSCI - 1900 to 6th July 2020) and the Cumulative Index to Nursing and Allied Health Literature (CINAHL - 1937 to 6th July 2020).

Comprehensive pre-planned search strategies similar to that in Table 1 were designed dependent on the electronic databases listed above and their individual MeSH terms. All key words and combinations were the same throughout the database searching.

\subsection{Other sources searched}

Grey literature was searched for using the Social Care Online database. The International Journal of Integrated Care was hand searched to find further relevant studies which may have been missed during the electronic database searches. Reference list searching of relevant literature reviews found during the electronic searches and the final included articles was conducted. Experts in the field of research were also contacted to identify other potentially relevant articles missed from the electronic searches.

\subsection{Study screening and selection}

Duplicate removal was conducted using Excel, one review author (RS) also hand searched the file for additional duplicates missed by the Excel duplicate removal process. Following duplicate removal, all review authors were involved in independently screening the titles and abstracts to identify studies fitting the inclusion criteria. Full texts of the selected articles were then scrutinised for inclusion. Where there was uncertainty about inclusion, consensus was achieved by discussion or the involvement of a third reviewer.

\subsection{Data extraction and management}

Data were extracted using standardised data extraction forms and subsequently entered into standardised tables. Data extracted included but was not limited to: author details; year of publication; publication type; participant demographic details; sample sizes; results, themes; key findings related to the experiences of integrated dementia care; and the

Table 1.

Example electronic search strategy conducted in MEDLINE.

\begin{tabular}{|c|c|c|}
\hline Concept & Search terms & \\
\hline $\begin{array}{l}\text { People living with } \\
\text { dementia }\end{array}$ & Alzheimer Disease, Dementia; Alzheimer\$; dement\$ & OR \\
\hline \multicolumn{3}{|l|}{ AND } \\
\hline Integrated care & $\begin{array}{l}\text { Delivery of Health Care; Integrated; integrat\$ care; } \\
\text { integrat\$ health; integrat\$ framework\$; integrat\$ } \\
\text { model\$; integrat\$ system\$; integrat\$ pathway\$; } \\
\text { integrat\$ program\$; integrat\$ working; integrat\$ } \\
\text { team\$; care integrat\$; case manage\$; care coordinat\$ }\end{array}$ & OR \\
\hline \multicolumn{3}{|l|}{ AND } \\
\hline $\begin{array}{l}\text { Experiences and } \\
\text { perceptions }\end{array}$ & $\begin{array}{l}\text { Experience\$; perception\$; perspective\$, facilitator\$; } \\
\text { barrier\$; enabler\$; view\$; patient satisfaction; personal } \\
\text { satisfaction; satisfaction }\end{array}$ & OR \\
\hline
\end{tabular}

Note: \$ denotes truncation; italics denotes MeSH terms study authors' conclusions.

\subsection{Quality appraisal}

The quality of included studies was assessed independently by at least two members of the research team using the qualitative research appraisal tool developed by Greenwood et al. (2009). This tool consists of 11 questions with 'yes' (one point) or 'no' (zero points) answers. Quality scores were not used to exclude studies, but to identify their strengths and weaknesses. Evidence has shown that excluding poor quality studies from qualitative reviews has little meaningful effect on the evidence synthesis (Carroll et al., 2012).

\subsection{Synthesis}

Data was synthesised using the four-stage approach for thematic synthesis as described by Thomas and Harden (2008). These four stages overlap to some degree but are described as follows - stage 1) extract data; 2) code text; 3) develop descriptive themes; and 4) generate analytical themes. Data synthesis was conducted by two study authors (RS and AM) who agreed on the final themes and subthemes after collaboration.

\section{Findings}

Electronic searches of six databases revealed 727 articles before duplicate removal: MEDLINE -145; Social Policy and Practice - 170; PsycINFO - 126; Social Sciences Citation Index - 73; CINAHL - 127; and Social Care Online - 86. After duplicate removal, 415 individual studies were identified from the electronic searches. After screening titles and abstracts, 59 full-text articles were retrieved. A further 10 full-texts were retrieved from hand searching the International Journal of Integrated Care; 16 from reference list searches of relevant reviews identified from the electronic searches; and 13 from reference list searches of already included articles identified from the above searches. No further relevant studies were identified from contact with experts in the field of integrated care research. Of the 98 full-texts retrieved, 23 fitted the inclusion criteria and were included in the thematic synthesis. Full details of the process of including and excluding articles with reasons is available in Fig. 1.

\subsection{Study details and participant characteristics}

The 23 included studies were published between 2006 and 2019, with the majority (17) published after 2014. Twelve were conducted in the United Kingdom (Bamford et al., 2014; Bunn et al., 2017; Carter et al., 2017; Davies et al. 2014; Gage et al., 2012; Kümpers et al. 2006; Kupeli et al., 2016; Piercy et al., 2018; Robertshaw \& Cross, 2017; Robertshaw \& Cross, 2018; Smith, 2016; Woolrych \& Sixsmith, 2013); three in Australia (Bauer et al., 2011; Luckett et al., 2017; Robinson et al., 2009); three in the Netherlands (de Lange et al., 2016; Minkman et al., 2009; van Mierlo et al., 2014); two in Canada (Heckman et al. 2019; Kosteniuk et al. 2014); two in Japan (Hirakawa et al., 2017; Hirakawa et al., 2019); and one in Spain (Risco et al. 2016). Apart from two mixed methods studies (Gage et al., 2012; Piercy et al., 2018), all were qualitative. Types of analysis varied, but was most often reported as thematic, content or framework analysis. All but four studies used face-to-face interviews, telephone interviews or focus groups for data collection, with the other four using internet forum posts (Robertshaw \& Cross, 2017; Robertshaw \& Cross, 2018) online focus groups (de Lange et al., 2016) or free text responses to a survey (Gage et al., 2012).

Care settings for the studies were primary community based, however three (Gage et al., 2012; Kupeli et al., 2016; Luckett et al., 2017) focussed on care provision in care homes. Twelve investigated the experiences and perceptions of health care professionals (e.g. GPs; nurses; social workers), care workers or programme managers (Bamford et al., 


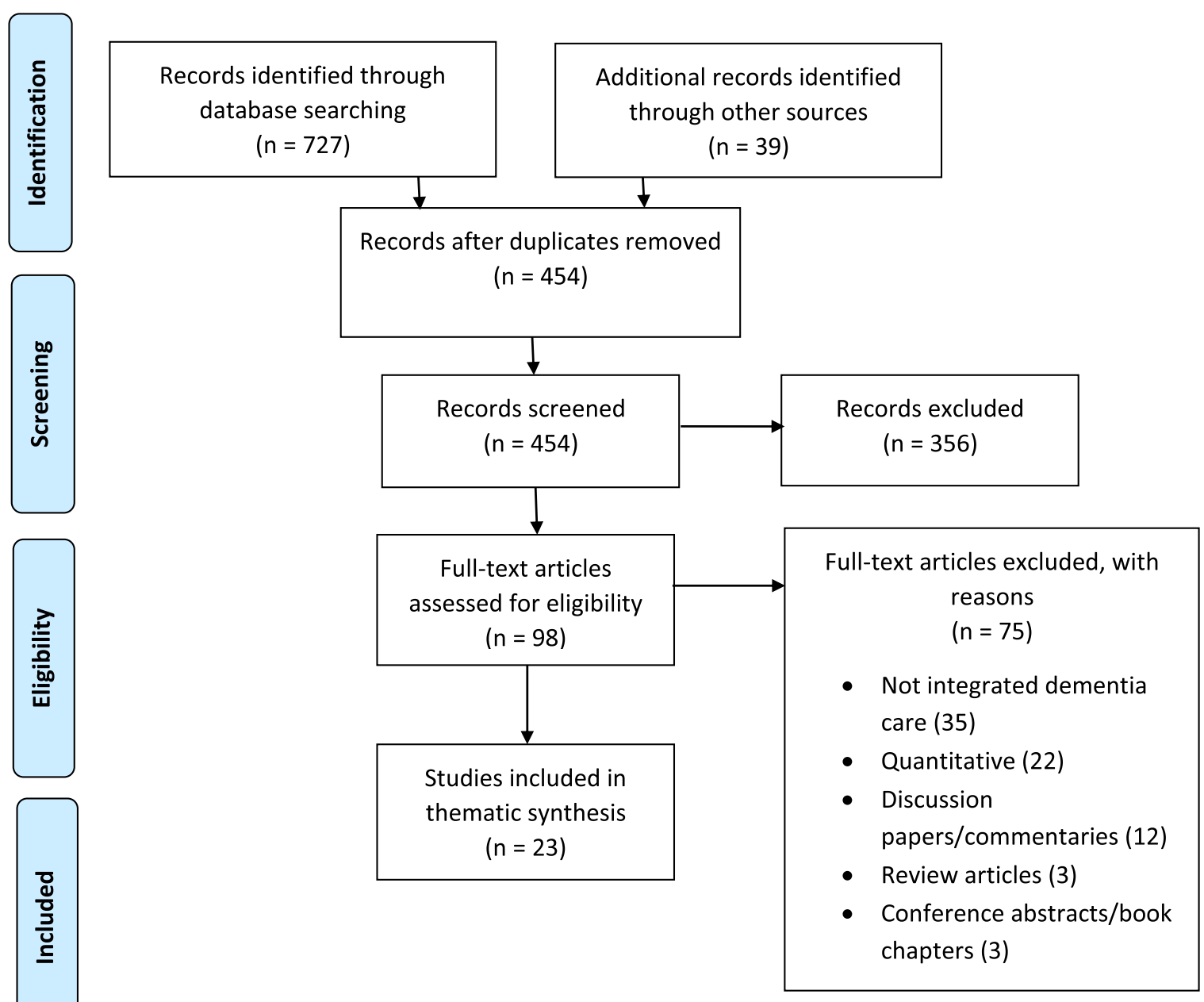

Fig. 1. PRISMA flow diagram (Moher et al. 2009) showing the process of article identification and selection.

2014; Carter et al., 2017; Davies et al. 2014; de Lange et al., 2016; Gage et al., 2012; Heckman et al. 2019; Hirakawa et al., 2017; Hirakawa et al., 2019; Kosteniuk et al., 2014; Kupeli et al., 2016; Luckett et al., 2017; Minkman et al., 2009; Piercy et al., 2018; Smith, 2016; van Mierlo et al., 2014; Woolrych \& Sixsmith, 2013); five included a combination of health care professionals and informal carers (Bunn et al., 2017; Kümpers et al. 2006; Risco et al. 2016; Robertshaw \& Cross, 2017; Robertshaw \& Cross, 2018) and two exclusively on informal carers (Bauer et al., 2011; Robinson et al., 2009). Three studies also included the perceptions of people living with dementia (Bamford et al., 2014; Bunn et al., 2017; Risco et al. 2016). Full details of the study details are available in Table 2.

\subsection{Quality scores}

Study quality was generally high, ranging from 6 (Smith, 2016) to 12 (Davies et al. 2014) out of a possible score of 12 using the Greenwood et al. (2009) quality assessment tool for qualitative studies. Sixteen studies were scored as nine or higher (Table 3 ). Most often lower scores $(<8)$ were given where studies had not adequately described the methods used; provided enough detail of the analysis performed; the study participants were not adequately described (e.g. lack of demographic information); and a lack of evidence that more than one researcher was involved in the data analysis.

\subsection{Themes}

Three overarching themes were identified: 1) Ways of working which facilitate the delivery of integrated dementia care; 2) Informal carers as equal partners in care provision and decision making; and 3) Challenges leading to fragmented and disjointed integrated dementia care. The themes with associated subthemes are presented Table 4 along with example quotations demonstrating each theme.

3.4. Theme 1: Ways of working which facilitate the delivery of integrated dementia care

The importance of interprofessional communication and collaboration

Thematic synthesis of the findings suggests that close cooperation and team working between case managers, other healthcare professionals and community organisations promotes integrated care and better meets the needs of people living with dementia and their families (de Lange et al., 2016; Robertshaw \& Cross, 2017; van Mierlo et al., 2014; Woolrych \& Sixsmith, 2013). Open and transparent communication and knowledge transfer were viewed as important for facilitating integrated care and allow healthcare professionals to effectively support people living with dementia with the limited resources available to them (de Lange et al., 2016; Kümpers et al. 2006). However, breakdowns in communication between healthcare professionals and community support services, results in a lack of team approach to care provision, poor knowledge transfer and inadequate integrated care (Carter et al., 2017; Risco et al. 2016). 
Table 2.

Aims and participant demographic characteristics.

\begin{tabular}{|c|c|c|c|c|c|c|}
\hline $\begin{array}{l}\text { Authors (Year } \\
\text { published) } \\
\text { [Country] }\end{array}$ & Aims & Care setting & Participant type and numbers & $\begin{array}{l}\text { Age in } \\
\text { yearsMean } \\
\text { [median] } \\
\text { (range) }\end{array}$ & $\begin{array}{l}\text { Gender } \\
(\%)\end{array}$ & $\begin{array}{l}\text { Ethnicity } \\
\text { (\%) }\end{array}$ \\
\hline $\begin{array}{l}\text { Bamford et al. } \\
\text { (2014) [UK] }\end{array}$ & $\begin{array}{l}\text { To explore the views and experiences of } \\
\text { patients, carers, case managers, health } \\
\text { and social care professionals of case } \\
\text { management. }\end{array}$ & $\begin{array}{l}\text { Community based - } \\
\text { GP practices }\end{array}$ & $\begin{array}{l}49 \text { (10 informal carers; } 9 \text { case managers; } \\
6 \text { PLWD; } 6 \text { GPs; } 5 \text { admin staff; } 4 \text { case } \\
\text { manager mentors; } 3 \text { volunteers; } 2 \\
\text { researchers; } 2 \text { community mental health } \\
\text { team; } 2 \text { commissioners) }\end{array}$ & NR & NR & NR \\
\hline $\begin{array}{l}\text { Bauer et al. } \\
\text { (2011) } \\
\text { [Australia] }\end{array}$ & $\begin{array}{l}\text { To explore whether hospital discharge } \\
\text { practices meets the needs of the family } \\
\text { carer of a person living with dementia. }\end{array}$ & Hospital discharge & 25 informal carers & NR & NR & NR \\
\hline $\begin{array}{l}\text { Bunn et al. (2017) } \\
\text { [UK] }\end{array}$ & $\begin{array}{l}\text { To explore the impact of dementia on } \\
\text { access to nondementia services and } \\
\text { identify ways of improving service } \\
\text { delivery for this population. }\end{array}$ & Community based & $\begin{array}{l}56 \text { HCPs (18 nurses; } 13 \text { consultants; } 10 \\
\text { GPs; } 9 \text { therapists; } 4 \text { 'other'; } 2 \text { managers); } \\
33 \text { informal carers } \\
28 \text { PLWD }\end{array}$ & $\begin{array}{l}\text { PLWD: } \\
\text { NR } \\
\text { [82.5] } \\
\text { (59-94) } \\
\text { Informal } \\
\text { carers: } \\
\text { NR } \\
\text { [65] } \\
(46-90)\end{array}$ & $\begin{array}{l}\text { PLWD: } \\
36 \% \\
\text { female } \\
\text { Informal } \\
\text { carers: } \\
82 \% \\
\text { female }\end{array}$ & $\begin{array}{l}\text { PLWD: } \\
85 \% \text { White } \\
\text { British } \\
\text { Informal } \\
\text { carers: } \\
85 \% \text { white } \\
\text { British }\end{array}$ \\
\hline $\begin{array}{l}\text { Carter et al. } \\
\text { (2017) [UK] }\end{array}$ & $\begin{array}{l}\text { To elicit GPs' perceptions of the } \\
\text { potential barriers and solutions to the } \\
\text { provision of good quality palliative care } \\
\text { in dementia in their practices. }\end{array}$ & $\begin{array}{l}\text { Community based - } \\
\text { GP practices }\end{array}$ & 138 GPs & NR & NR & NR \\
\hline $\begin{array}{l}\text { Davies et al. } \\
\text { (2014) [UK] }\end{array}$ & $\begin{array}{l}\text { To explore professional perspectives on } \\
\text { barriers to the delivery of high-quality } \\
\text { palliative care for people with dementia. }\end{array}$ & $\begin{array}{l}\text { Various (community } \\
\text { and care home } \\
\text { setting) }\end{array}$ & $\begin{array}{l}39 \text { HCPs ( } 18 \text { clinical practitioners, } \\
\text { including GPs, nurses and old age } \\
\text { psychiatrists; } 13 \text { care home managers/ } \\
\text { directors; } 6 \text { senior managers; } 2 \\
\text { researchers) }\end{array}$ & NR & NR & NR \\
\hline $\begin{array}{l}\text { de Lange et al. } \\
\text { (2016) [The } \\
\text { Netherlands] }\end{array}$ & $\begin{array}{l}\text { To obtain insight into facilitating factors } \\
\text { for case management in dementia care. }\end{array}$ & Community based & $\begin{array}{l}99 \text { HCPs ( } 42 \text { case managers; } 17 \text { nurses; } \\
14 \text { neurologists; } 9 \text { general practitioners; } \\
9 \text { project leaders; } 3 \text { managers; } 2 \\
\text { psychologists; } 1 \text { nursing assistant; } 1 \\
\text { policy maker; } 1 \text { lobbyist) }\end{array}$ & NR & NR & NR \\
\hline $\begin{array}{l}\text { Gage et al. (2012) } \\
\text { [UK] }\end{array}$ & $\begin{array}{l}\text { To establish the current extent of } \\
\text { integrated working that exists between } \\
\text { care homes and primary and community } \\
\text { health and social services. }\end{array}$ & Care homes & 89 care home managers & NR & NR & NR \\
\hline $\begin{array}{l}\text { Heckman et al. } \\
\text { (2019) } \\
\text { [Canada] }\end{array}$ & $\begin{array}{l}\text { To understand physicians' and } \\
\text { specialists' perspectives on an integrated } \\
\text { dementia care system and identify } \\
\text { barriers to its implementation. }\end{array}$ & Community based & 10 primary care doctors & NR & NR & NR \\
\hline $\begin{array}{l}\text { Hirakawa et al. } \\
\text { (2017) [Japan] }\end{array}$ & $\begin{array}{l}\text { To identify the barriers to achieving } \\
\text { efficient cooperation and coordination } \\
\text { among HCPs. }\end{array}$ & Community based & $\begin{array}{l}13 \text { HCPs ( } 4 \text { directors; } 4 \text { social workers; } 3 \\
\text { nurses; } 2 \text { care managers) }\end{array}$ & NR & NR & NR \\
\hline $\begin{array}{l}\text { Hirakawa et al. } \\
\text { (2019) [Japan] }\end{array}$ & $\begin{array}{l}\text { To identify key challenges to successful } \\
\text { community-based integrated team } \\
\text { approach to the management of older } \\
\text { adults with dementia. }\end{array}$ & Community based & $\begin{array}{l}13 \text { informal carers; } \\
24 \text { HCPs ( } 8 \text { doctors; } 8 \text { nurses; } 6 \text { social } \\
\text { workers; } 1 \text { pharmacist; } 1 \text { nursing home } \\
\text { manager) }\end{array}$ & NR & $\begin{array}{l}23 \\
\text { females; } \\
14 \text { males }\end{array}$ & NR \\
\hline $\begin{array}{l}\text { Kosteniuk et al. } \\
\text { (2014) } \\
\text { [Canada] }\end{array}$ & $\begin{array}{l}\text { To explore family doctors' views } \\
\text { regarding this issue, their role in } \\
\text { providing dementia care, and the } \\
\text { implications of providing dementia care } \\
\text { in a rural setting. }\end{array}$ & Community based & 15 family doctors/general practitioners & NR & $\begin{array}{l}13 \text { males; } \\
2 \text { females }\end{array}$ & NR \\
\hline $\begin{array}{l}\text { Kümpers et al. } \\
\text { (2006) [UK \& } \\
\text { the } \\
\text { Netherlands] }\end{array}$ & $\begin{array}{l}\text { To explore the importance of knowledge } \\
\text { transfer between specialist and generic } \\
\text { services in improving health care. }\end{array}$ & Community based & $\begin{array}{l}29 \text { HCPs (e.g. nurses; social workers and } \\
\text { therapists); } \\
20 \text { HCPs in management positions; } \\
20 \text { informal carers; } \\
19 \text { medical doctors; } \\
12 \text { managers }\end{array}$ & NR & NR & NR \\
\hline $\begin{array}{l}\text { Kupeli et al. } \\
\text { (2016) [UK] }\end{array}$ & $\begin{array}{l}\text { To identify the barriers to providing } \\
\text { integrated care as understood by care } \\
\text { professionals working with people with } \\
\text { advanced dementia residing in care } \\
\text { homes. }\end{array}$ & $\begin{array}{l}\text { Care homes for } \\
\text { people with } \\
\text { advanced dementia }\end{array}$ & $\begin{array}{l}14 \text { HCPs ( } 5 \text { nurses; } 3 \text { healthcare } \\
\text { assistants; } 2 \text { care home managers; } 2 \\
\text { commissioners; } 1 \text { clinical manager; } 1 \\
\text { occupational therapist) }\end{array}$ & NR & NR & NR \\
\hline $\begin{array}{l}\text { Luckett et al. } \\
\qquad \text { (2017) } \\
\text { [Australia] }\end{array}$ & $\begin{array}{l}\text { To explore Palliative Care Planning } \\
\text { Coordinators and health professional } \\
\text { perceptions of the benefits of facilitated } \\
\text { case conferencing and identify factors } \\
\text { influencing implementation. }\end{array}$ & Care homes & $\begin{array}{l}40 \text { HCPs (18 nurses; } 11 \text { palliative care } \\
\text { planning coordinators; } 8 \text { allied health } \\
\text { workers; } 3 \text { medical doctors) }\end{array}$ & NR & NR & NR \\
\hline $\begin{array}{l}\text { Minkman et al. } \\
\text { (2009) [The } \\
\text { Netherlands] }\end{array}$ & $\begin{array}{l}\text { To describe and analyse a new approach } \\
\text { in extensive case management } \\
\text { programmes concerned with long-term } \\
\text { dementia care in The Netherlands. }\end{array}$ & Community based & 16 programme managers & NR & NR & NR \\
\hline
\end{tabular}


Table 2. (continued)

\begin{tabular}{|c|c|c|c|c|c|c|}
\hline $\begin{array}{l}\text { Authors (Year } \\
\text { published) } \\
\text { [Country] }\end{array}$ & Aims & Care setting & Participant type and numbers & $\begin{array}{l}\text { Age in } \\
\text { yearsMean } \\
\text { [median] } \\
\text { (range) }\end{array}$ & $\begin{array}{l}\text { Gender } \\
(\%)\end{array}$ & $\begin{array}{l}\text { Ethnicity } \\
(\%)\end{array}$ \\
\hline $\begin{array}{l}\text { Piercy et al. } \\
\text { (2018) [UK] }\end{array}$ & $\begin{array}{l}\text { To assess how well an integrated service } \\
\text { for post diagnostic dementia care had } \\
\text { performed in providing support to PWD } \\
\text { and their family/carers. }\end{array}$ & Community based & $\begin{array}{l}17 \text { ( } 7 \text { dementia advisers; } 6 \text { partner } \\
\text { organisation representatives; } 3 \text { Admiral } \\
\text { nurses; } 1 \text { service administrator) }\end{array}$ & NR & NR & NR \\
\hline $\begin{array}{l}\text { Risco et al. } \\
\text { (2016) [Spain] }\end{array}$ & $\begin{array}{l}\text { To identify the barriers and facilitators } \\
\text { in dementia care with respect to } \\
\text { information provision, communication, } \\
\text { and collaboration from the perspectives } \\
\text { of the person with dementia, family } \\
\text { caregivers, and health care professionals }\end{array}$ & $\begin{array}{l}\text { Various (care homes; } \\
\text { hospitals and } \\
\text { community settings) }\end{array}$ & $\begin{array}{l}19 \text { HCPs ( } 10 \text { medical doctors; } 5 \text { nurses; } \\
4 \text { social workers) } \\
11 \text { informal carers } \\
7 \text { PLWD }\end{array}$ & $\begin{array}{l}\text { PLWD: } \\
74.2 \\
\text { [NR] } \\
(63-81) \\
\text { Informal } \\
\text { carers: } \\
78.3 \\
\text { [NR] } \\
(65-92) \\
\text { HCPs: } \\
41.2 \\
\text { [NR] } \\
(31-53)\end{array}$ & NR & NR \\
\hline $\begin{array}{l}\text { Robertshaw \& } \\
\text { Cross (2017) } \\
\text { [UK] }\end{array}$ & $\begin{array}{l}\text { To understand the views and } \\
\text { experiences of integrated health and } \\
\text { social care for dementia from the } \\
\text { perspective of carers, families, } \\
\text { healthcare professionals and } \\
\text { researchers. }\end{array}$ & $\begin{array}{l}\text { Various } \\
\text { (Internet forum and } \\
\text { training module for } \\
\text { those providing care } \\
\text { to PLWD) }\end{array}$ & $\begin{array}{l}\text { Informal carers, care workers and } \\
\text { researchers ( } 3058 \text { participants took part } \\
\text { in the training course, NR how many } \\
\text { provided the } 847 \text { forum posts) }\end{array}$ & NR & $\begin{array}{l}\text { NR } \\
(83 \% \\
\text { female })\end{array}$ & NR \\
\hline $\begin{array}{l}\text { Robertshaw \& } \\
\text { Cross (2018) } \\
\text { [UK] }\end{array}$ & $\begin{array}{l}\text { To characterise roles and responsibilities } \\
\text { in relation to integrated care from the } \\
\text { perspective of massive open online } \\
\text { course (MOOC) participants }\end{array}$ & $\begin{array}{l}\text { Various } \\
\text { (Internet forum and } \\
\text { training module for } \\
\text { those providing care } \\
\text { to PLWD) }\end{array}$ & $\begin{array}{l}3058 \text { informal carers, care workers and } \\
\text { researchers (same participants as above } \\
\text { - participant numbers not counted twice } \\
\text { in reporting this review) }\end{array}$ & NR & $\begin{array}{l}\text { NR } \\
(83 \% \\
\text { female })\end{array}$ & NR \\
\hline $\begin{array}{l}\text { Robinson et al. } \\
\text { (2009) } \\
\text { [Australia] }\end{array}$ & $\begin{array}{l}\text { To identify and describe the experiences } \\
\text { of family carers of people with dementia } \\
\text { in accessing relevant information and } \\
\text { services in Southern Tasmania, } \\
\text { Australia. }\end{array}$ & Community based & 15 informal carers & $\begin{array}{l}\text { NR (ages are } \\
\text { ranked; unable } \\
\text { to separate out) }\end{array}$ & $\begin{array}{l}10 \\
\text { females; } \\
5 \text { males }\end{array}$ & NR \\
\hline $\begin{array}{l}\text { Smith (2016) } \\
\text { [UK] }\end{array}$ & $\begin{array}{l}\text { To explore the experiences of } \\
\text { community pharmacies delivering } \\
\text { services to people affected by dementia, } \\
\text { and the facilitators and barriers to these } \\
\text { services. }\end{array}$ & Community based & $\begin{array}{l}10 \text { HCPs (7 pharmacists; } 2 \text { technicians; } 1 \\
\text { nurse) }\end{array}$ & NR & NR & NR \\
\hline $\begin{array}{l}\text { van Mierlo et al. } \\
\text { (2014) (The } \\
\text { Netherlands] }\end{array}$ & $\begin{array}{l}\text { To provide insight into facilitators and } \\
\text { barriers to the delivery of community- } \\
\text { based personalised dementia care of two } \\
\text { different case management models. }\end{array}$ & Community based & $\begin{array}{l}22 \text { HCPs ( } 5 \text { care co-ordinators; } 3 \\
\text { Alzheimer Netherlands workers; } 3 \\
\text { stakeholders from municipalities; } 2 \text { case } \\
\text { managers; } 2 \text { GPs; } 2 \text { health insurance } \\
\text { workers; } 2 \text { mental health; professionals; } \\
2 \text { day care centre co-ordinators; } 1 \\
\text { informal carer support worker). }\end{array}$ & NR & NR & NR \\
\hline $\begin{array}{l}\text { Woolrych \& } \\
\text { Sixsmith } \\
\text { (2013) [UK] }\end{array}$ & $\begin{array}{l}\text { To understand the experiences of formal } \\
\text { carers working with the context of an } \\
\text { integrated dementia service. }\end{array}$ & Community based & 15 care workers & NR & NR & NR \\
\hline
\end{tabular}

$\mathrm{NR}=$ not reported; PLWD = people living with dementia; HCPs = healthcare professionals; GPs = general practitioners

Whilst some care home managers and care workers reported good working relationships with National Health Service (NHS) and other external healthcare professionals, communication difficulties were often reported when working with secondary care services, such as: poor information sharing; lack of care planning; and little follow up of people living with dementia who have recently left hospital (Gage et al., 2012; Kupeli et al., 2016). Professional hierarchies between specialists and generalists were described as barriers to effective communication (Kümpers et al. 2006).

To overcome challenges associated with interprofessional communication and collaboration, health and social care services need to be seamlessly joined up, allowing close working relationships between healthcare professionals for integrated care to develop (Bunn et al., 2017; Davies et al. 2014; Kosteniuk et al., 2014; Piercy et al., 2018). Some healthcare professionals and specialists were proactively developing working arrangements which promoted collaboration and approaches to integrate care (Heckman et al. 2019). Healthcare professionals meeting either face-to-face or via case conferencing to discuss clients' needs has been shown to increase knowledge transfer, improve integrated care and highlighted changing care needs for people living with dementia (Kümpers et al. 2006; Luckett et al., 2017; Piercy et al., 2018). A way of improving communication and collaboration among healthcare professionals was through the development of multidisciplinary teams.

\section{Working together in multidisciplinary teams}

Bringing together multidisciplinary teams (e.g. geriatricians, dementia special nurses, social workers, case managers, etc.) to provide care for people living with dementia, both in care homes and living in the community, was an important factor in providing good quality integrated care. Comprehensive input from a wide range of specialists, care workers, people living with dementia and their families, was described as offering the best outcomes for people living with dementia with regards to decision making surrounding care provision (Hirakawa et al., 2017; Kosteniuk et al., 2014). It also enabled healthcare workers to develop a holistic understanding of the person living with dementia as a whole and what their needs were, as opposed to just treating their symptoms (Robertshaw \& Cross, 2017). Where multidisciplinary teams 
Table 3

Methods and quality scores.

\begin{tabular}{|c|c|c|c|c|c|}
\hline $\begin{array}{l}\text { Authors (Year published) } \\
\text { [Country] }\end{array}$ & Study type and design & Sampling & Data collection & Data analysis & $\begin{array}{l}\text { Quality } \\
\text { scores }\end{array}$ \\
\hline $\begin{array}{l}\text { Bamford et al. (2014) } \\
\text { [UK] }\end{array}$ & $\begin{array}{l}\text { Qualitative; cross- } \\
\text { sectional }\end{array}$ & Purposive & $\begin{array}{l}\text { Ethnographic methods (in-depth } \\
\text { interviews; informal discussion and } \\
\text { observations) }\end{array}$ & $\begin{array}{l}\text { Constant comparative approach } \\
\text { and Normalisation Process Theory }\end{array}$ & 9 \\
\hline $\begin{array}{l}\text { Bauer et al. (2011) } \\
\text { [Australia] }\end{array}$ & $\begin{array}{l}\text { Qualitative; cross- } \\
\text { sectional }\end{array}$ & Purposive & Semi-structured face-to-face interviews & $\begin{array}{l}\text { Comparative method of thematic } \\
\text { analysis }\end{array}$ & 11 \\
\hline Bunn et al. (2017) [UK] & $\begin{array}{l}\text { Qualitative; cross- } \\
\text { sectional }\end{array}$ & Purposive & $\begin{array}{l}\text { In-depth semi-structured interviews and } \\
\text { focus groups }\end{array}$ & Thematic content analysis & 9 \\
\hline Carter et al. (2017) [UK] & $\begin{array}{l}\text { Qualitative; cross- } \\
\text { sectional }\end{array}$ & Convenience & $\begin{array}{l}\text { Postal survey with free-text qualitative } \\
\text { responses }\end{array}$ & Thematic analysis & 9 \\
\hline Davies et al. (2014) [UK] & $\begin{array}{l}\text { Qualitative; cross- } \\
\text { sectional }\end{array}$ & $\begin{array}{l}\text { Purposive and } \\
\text { snowballing }\end{array}$ & $\begin{array}{l}\text { Semi-structured face-to-face interviews, } \\
\text { telephone interviews, focus groups }\end{array}$ & Thematic analysis & 12 \\
\hline $\begin{array}{l}\text { de Lange et al. (2016) } \\
\text { [The Netherlands] }\end{array}$ & $\begin{array}{l}\text { Qualitative; cross- } \\
\text { sectional }\end{array}$ & Purposive & Online focus groups & Eclectic inductive method & 11 \\
\hline Gage et al. (2012) [UK] & Mixed methods & $\begin{array}{l}\text { Convenience national } \\
\text { sample of care homes }\end{array}$ & $\begin{array}{l}\text { Online survey with free-text responses } \\
\text { for qualitative data }\end{array}$ & Thematically coded & 10 \\
\hline $\begin{array}{l}\text { Heckman et al. (2019) } \\
\text { [Canada] }\end{array}$ & $\begin{array}{l}\text { Qualitative; cross- } \\
\text { sectional }\end{array}$ & $\begin{array}{l}\text { Random (random } \\
\text { number generator) }\end{array}$ & Telephone interviews & Naturalistic enquiry approach & 8 \\
\hline $\begin{array}{l}\text { Hirakawa et al. (2017) } \\
\text { [Japan] }\end{array}$ & $\begin{array}{l}\text { Qualitative; cross- } \\
\text { sectional }\end{array}$ & Purposive & Focus groups & Content analysis & 9 \\
\hline $\begin{array}{l}\text { Hirakawa et al. (2019) } \\
\text { [Japan] }\end{array}$ & $\begin{array}{l}\text { Qualitative; cross- } \\
\text { sectional }\end{array}$ & Purposive & Face-to-face interviews & Content analysis & 11 \\
\hline $\begin{array}{l}\text { Kosteniuk et al. (2014) } \\
\text { [Canada] }\end{array}$ & $\begin{array}{l}\text { Qualitative; cross- } \\
\text { sectional }\end{array}$ & Purposive & Telephone interviews & 'Coded by identifying themes' & 8 \\
\hline $\begin{array}{l}\text { Kümpers et al. (2006) [UK } \\
\text { \& the Netherlands] }\end{array}$ & $\begin{array}{l}\text { Qualitative; cross- } \\
\text { sectional }\end{array}$ & Purposive & Semi-structured in-depth interviews & $\begin{array}{l}\text { Data summarised into main topics } \\
\text { and then coded }\end{array}$ & 10 \\
\hline Kupeli et al. (2016) [UK] & $\begin{array}{l}\text { Qualitative; cross- } \\
\text { sectional }\end{array}$ & Purposive & Interactive interviews & Thematic analysis & 9 \\
\hline $\begin{array}{l}\text { Luckett et al. (2017) } \\
\text { [Australia] }\end{array}$ & $\begin{array}{l}\text { Qualitative (sub- } \\
\text { study); cross-sectional }\end{array}$ & $\begin{array}{l}\text { Purposive and } \\
\text { snowballing }\end{array}$ & $\begin{array}{l}\text { Face-to-face semi-structured and } \\
\text { telephone interviews }\end{array}$ & Thematic framework approach & 10 \\
\hline $\begin{array}{l}\text { Minkman et al. (2009) } \\
\text { [The Netherlands] }\end{array}$ & $\begin{array}{l}\text { Qualitative; multiple } \\
\text { case studies }\end{array}$ & Purposive & Face-to-face Semi-structured interviews & $\begin{array}{l}\text { Construction of tables of core } \\
\text { characteristics. Structured } \\
\text { overviews }\end{array}$ & 8 \\
\hline Piercy et al. (2018) [UK] & Mixed methods & Purposive & $\begin{array}{l}\text { Focus groups and face-to-face semi- } \\
\text { structured interviews }\end{array}$ & Framework analysis & 11 \\
\hline Risco et al. (2016) [Spain] & $\begin{array}{l}\text { Qualitative; cross- } \\
\text { sectional }\end{array}$ & Purposive & Focus groups & Content analysis & 11 \\
\hline $\begin{array}{l}\text { Robertshaw \& Cross } \\
\text { (2017) [UK] }\end{array}$ & $\begin{array}{l}\text { Qualitative; cross- } \\
\text { sectional }\end{array}$ & Convenience & Internet forum responses & Framework analysis & 8 \\
\hline $\begin{array}{l}\text { Robertshaw \& Cross } \\
\text { (2018) [UK] }\end{array}$ & $\begin{array}{l}\text { Qualitative; cross- } \\
\text { sectional }\end{array}$ & Convenience & Internet forum responses & Framework analysis & 9 \\
\hline $\begin{array}{l}\text { Robinson et al. (2009) } \\
\text { [Australia] }\end{array}$ & $\begin{array}{l}\text { Qualitative; cross- } \\
\text { sectional }\end{array}$ & Purposive & Focus groups & Iterative/thematic analysis & 8 \\
\hline Smith (2016) [UK] & $\begin{array}{l}\text { Qualitative; cross- } \\
\text { sectional }\end{array}$ & Purposive & Semi-structured interviews & NR & 6 \\
\hline $\begin{array}{l}\text { Van Mierlo et al. (2014) } \\
\text { (The Netherlands] }\end{array}$ & $\begin{array}{l}\text { Qualitative; cross- } \\
\text { sectional }\end{array}$ & Purposive & Semi-structured interviews & Directed content analysis & 11 \\
\hline $\begin{array}{l}\text { Woolrych \& Sixsmith } \\
\text { (2013) [UK] }\end{array}$ & $\begin{array}{l}\text { Qualitative; cross- } \\
\text { sectional }\end{array}$ & Purposive & $\begin{array}{l}\text { Face-to-face semi-structured interviews } \\
\text { and focus groups }\end{array}$ & Thematic analysis & 8 \\
\hline
\end{tabular}

$\mathrm{NR}=$ not reported.

did not exist, care was described as chaotic, disorganised and fragmented (Davies et al. 2014).

A lack of general practitioner (GP) integration with specialist support services, as well as patients being treated by generalists as opposed to specialist clinicians, was viewed as disjointed and a hindrance in providing integrated care (Carter et al., 2017; Davies et al. 2014). However, where GPs and other specialists were involved in decision making within multidisciplinary teams, medical concerns could be actioned quicker (Luckett et al., 2017). Further, where case managers were part of multidisciplinary teams, they could inform clinicians of challenges, thereby facilitating discussion and resolving issues (Minkman et al., 2009). Developing multidisciplinary teams with one person designated for co-ordinating dementia care (e.g. case managers) was regarded as a way of improving integrated care and better meeting the needs of those being cared for (Carter et al., 2017; Davies et al. 2014).

\section{Case managers: a point of contact and facilitating access to services}

Case managers (also known as: care managers; care navigators and care coordinators) often acted as the first point of contact for informal carers and people living with dementia, facilitating access to various services and healthcare professionals, reducing the need for them to contact multiple service providers (Bamford et al., 2014; Bunn et al., 2017; Robertshaw \& Cross, 2017; Robertshaw \& Cross, 2018; van Mierlo et al., 2014). They had an important role in overseeing the care for people living with dementia. Making sure they were receiving the services they needed and identifying any changing needs (Kosteniuk et al., 2014). Advanced levels of education, adequate training in understanding the needs of people living with dementia, communication skills and knowledge of appropriate local services were identified as important skills for case managers to have to be effective in their role (de Lange et al., 2016; Minkman et al., 2009; van Mierlo et al., 2014; Woolrych \& Sixsmith, 2013).

Case managers having regular contact with GPs and other health care professionals helped with speeding up referrals and identifying the changing needs of people living with dementia (de Lange et al., 2016). Ideally case managers would be imbedded into GP surgeries to be most effective in their role through communicating with other clinicians, but this rarely happened in practice (Bamford et al., 2014; de Lange et al., 
2016). For the long-term success of case managers, strong collaboration and communication between them and other health care professionals was critical (van Mierlo et al., 2014). However, a lack of clarity and confusion was discussed over how the case manager role is different from other clinical roles which require caring for people living with dementia, for example: Admiral Nurses and mental health nurses (Bamford et al., 2014; van Mierlo et al., 2014).

Case management was often most effective if offered to informal carers and people living with dementia soon after diagnosis (Bamford et al., 2014). This can be for various reasons, notably for assisting informal carers navigate complicated care systems and being one point of contact for people living with dementia and their families.

\subsection{Theme 2: Informal carers as equal partners in care provision and decision making}

Involving informal carers in decision making for improved care integration

Involving informal carers in decision making and the care of the person living with dementia was described as an integral part of providing good quality integrated care. Healthcare professionals needed to take adequate time to listen to their concerns and understand their needs (Bamford et al., 2014). This was especially important given the active role informal carers have in facilitating care, for example; keeping records of medical tests and transferring records and information between different service providers (Bunn et al., 2017). However, informal carers were often not informed of changes in care provision due to a breakdown in communication, which not only caused stress, but could also make them feel undervalued, excluded from decision making and necessitated them searching out information by themselves (Bauer et al., 2011; Bunn et al., 2017; Risco et al. 2016; Robinson et al., 2009). Informal carer stress can be compounded by difficulties they experience in accessing services (e.g. having to repeat the same information to various service providers) and the perception that services are poorly organised and confusing to access (Hirakawa et al., 2019; Robinson et al., 2009; van Mierlo et al., 2014; Woolrych \& Sixsmith, 2013).

In addition to telephone and face-to-face meetings, conference calling was shown to provide a person-centred approach to improving communication between nursing home staff and informal carers, allowing informal carers to be more involved with decision making (Luckett et al., 2017). Healthcare professionals communicating effectively and sharing information with informal carers has been shown to facilitate high quality integrated care for people living with dementia in the community (Hirakawa et al., 2017). Supporting informal carers and involving them with decision making can also positively impact on continuity of care for people living with dementia through improved care integration and coordination.

Coordinating care to ensure continuity: reducing stress on informal carers and people living with dementia

Seamless continuity of care, whereby the sharing of patient information between healthcare professionals, people living with dementia and their informal carers, was found to be essential for effective service coordination and the provision of good quality integrated dementia care (Robertshaw \& Cross, 2017). The ability to have one point of contact, as opposed to informal carers or people living with dementia having to contact numerous services, was highly valued (Bamford et al., 2014; Piercy et al., 2018; Robinson et al., 2009). Providing multiple care services (e.g. respite; day care; outreach) within one integrated service was viewed by care workers to offer clients better continuity of care and provide more flexibility when referring clients from one service to another (Woolrych \& Sixsmith, 2013). Where a lack of care continuity was discussed, it often led to the perception of poor organisation and coordination on the part of the care providers and could negatively impact on the health and wellbeing of people living with dementia and their families (Bauer et al., 2011; Bunn et al., 2017). This lack of coordination to care provision was likely to be more pronounced in rural areas due to fragmented services, leading to poor integrated care and health inequalities (Hirakawa et al., 2019; Kosteniuk et al., 2014). In care homes, having staff specifically assigned to providing care for certain residents was described as a way of improving care continuity (Kupeli et al., 2016). This was also found in the community, with healthcare staff able to build up trusting relationships with people living with dementia and informal carers (Piercy et al., 2018). However, high staff turnover could negatively affect this, especially with regards to loss of relationships and knowledge transfer between healthcare professionals (Kümpers et al. 2006; Kupeli et al., 2016). Subsequently, fragmented and lack of care continuity could lead to confusion, conflict and frustration for people living with dementia and their carers (Risco et al. 2016; Robertshaw \& Cross, 2018).

\subsection{Theme 3: Challenges leading to fragmented and disjointed integrated dementia care}

\section{Distrust amongst health care professionals}

General practitioners perceived that a poor interdisciplinary team approach was a barrier to providing good quality integrated dementia care (Carter et al., 2017). However, this view was also shared by clinicians from other disciplines, in that it could be difficult to collaborate with GPs. Those healthcare professionals working in care homes reported finding it challenging to engage with GPs and described difficulty having them visit residents in the care home, subsequently affecting the frequency of necessary medication changes (Gage et al., 2012). Further, some care home employees held a general view that it was difficult to work with some external healthcare professionals as they did not fully understand the workings of care homes, leading to distrust and a breakdown of working relationships (Gage et al., 2012; Kupeli et al., 2016). The importance of developing strong working relationships were also described in other settings, for example, memory clinics. However, a lack of understanding, a perceived poor attitude of some specialists, and GPs having too little time to fully engage in dementia care acted as barriers to adequately integrating care (Heckman et al. 2019; Kosteniuk et al., 2014; Minkman et al., 2009; van Mierlo et al., 2014).

Some healthcare professionals were reluctant to consult psychiatrists, despite their importance in a community based integrated dementia care system. This could be due to poor understanding of the role of psychiatrists in dementia care or through fear the people living with dementia might be prescribed strong antipsychotic medications (Hirakawa et al., 2019). Distrust between healthcare professionals from different clinical backgrounds could result in poor care integration through poor knowledge exchange. Clinicians who were reassuring and respectful to each other when describing the care of a person with dementia improved trust and interdisciplinary team working (Kümpers et al. 2006). Despite challenges to interprofessional working relationships, a major factor in inadequate information sharing and collaboration is due to challenges involved with accessing client information.

\section{Challenges in accessing and sharing information}

Healthcare professionals often described how current infrastructure did not support the sharing of information across different specialities, with some being unaware a person had a dementia diagnosis (Bunn et al., 2017). This lack of access to information on clients also prevented seamless team working and integration of care (Smith, 2016). For example, care home staff reported finding it challenging to access and share information with NHS services (Gage et al., 2012), resulting in the duplication of work and increasing pressure on services already under strain due to capacity and time constraints (Piercy et al., 2018).

To overcome barriers to accessing and sharing information, there needs to be standardised electronic medical records stored in a central location which healthcare professionals, care workers and specialists can access to ensure good quality person-centred care and integrated care (Heckman et al. 2019; Robertshaw \& Cross, 2018; Woolrych \& Sixsmith, 2013). However, legal barriers were identified as reasons for 
not sharing information with services and families which can inhibit early intervention (Hirakawa et al., 2019).

\section{Lack of funding and limited resources}

The lack of funding and resources available was described as the greatest barrier to providing good quality integrated care for people living with dementia (Robertshaw \& Cross, 2017). The lack of secure funding for case managers' roles led to uncertainty among healthcare professionals surrounding the ongoing service they could provide people living with dementia and their families (de Lange et al., 2016; Minkman et al., 2009).

Time restraints, a lack of resources, and poor access to specialists can negatively impact upon care integration and knowledge transfer between case managers and healthcare professionals (Heckman et al. 2019; Kümpers et al. 2006; Robertshaw \& Cross, 2018). With regards to care homes, some care workers felt they were driven by profit as opposed to providing optimal care, and that some are poorly equipped to provide integrated end of life care to people living with dementia (Kupeli et al., 2016).

Where integrated care has been successful, it should prevent the duplication of service provision by adequately allocating resources and providing consistent continuity of care (Robertshaw \& Cross, 2018). However, whilst integrated care was viewed as desirable by healthcare professionals, they suggested that it could only be provided within the boundaries and constraints of the current system, with little flexibility beyond that (Woolrych \& Sixsmith, 2013).

\section{Discussion}

This qualitative evidence synthesis set out to explore the experience of integrated dementia care from the perspectives of those accessing services and those providing them. Thematic synthesis of the included studies showed that for integrated care to be successful, communication and collaboration between healthcare professionals and the involvement of informal carers are crucial, particularly for providing long-term continuity of care for people living with dementia. Effective communication and collaboration can potentially be achieved through the use of multidisciplinary teams and employing case managers to oversee care provision. However, distrust between healthcare professionals from different clinical disciplines and pressures on time and resources often hinder the development of integrated dementia care. These, combined with poor access to a central database where information on clients can be stored and shared amongst healthcare professionals, often leads to fragmented and disjointed care provision, resulting in negative experiences for people living with dementia and their families.

The negative consequences of fragmented and disjointed integrated dementia care are numerous (Department of Health \& Social Care, 2013), including unnecessary health and social care professional visits, emergency hospital admissions, remaining in hospital longer than necessary, and unreliable transitions through care pathways (Kar, 2015). It is, therefore, vital that 'joined up' ways of working between healthcare professionals from both health and social care services are encouraged and facilitated to enable reliable, person-centred care for people living with dementia. However, the barriers identified in this review, including distrust between healthcare professionals and a lack of resources, are likely to hinder the development of truly integrated service provision. Therefore, service managers and clinicians should seek to develop open, honest and respectful dialogue with those working in other services to build secure working relationships. These types of communication enablers have been found previously, with information sharing needing to be open, two-way and inclusive of all healthcare team members (Lawn et al., 2015).

With recent policy documents focusing on increasing and improving integrated dementia care in many European countries (Alzheimer Europe, 2017; DH, 2009; Wright \& O'Connor, 2018), the findings of this review should prove useful for developing integrated services which

Table 4.

Themes, subthemes and representative quotes from included articles.

\begin{tabular}{|c|c|c|}
\hline Themes & Subthemes & Representative quotes \\
\hline $\begin{array}{l}\text { 1. Ways of working } \\
\text { which facilitate the } \\
\text { delivery of } \\
\text { integrated } \\
\text { dementia care }\end{array}$ & $\begin{array}{l}\text { The importance of } \\
\text { interprofessional } \\
\text { communication and } \\
\text { collaboration }\end{array}$ & $\begin{array}{l}\text { "We need clear } \\
\text { collaboration agreements } \\
\text { between care providers in the } \\
\text { dementia care network, } \\
\text { between general practitioner } \\
\text { and case manager, but also } \\
\text { between specialist in geriatric } \\
\text { medicine or psychologist and } \\
\text { case manager." (de Lange } \\
\text { et al., 2016) } \\
\text { "It's about joining it (health } \\
\text { and social care teams) all } \\
\text { up, isn't it?" (Davies et al. } \\
\text { 2014) }\end{array}$ \\
\hline
\end{tabular}

Working together in multidisciplinary teams

"I can ascertain that somebody doesn't know who the prime minister is, doesn't know what today is, and can't remember what they had for breakfast. I don't really need a neurologist to tell me that. I need a neurologist to help me with the subtleties and I think a team would be much better." (Kosteniuk et al., 2014).

"True integrated care should involve a seamless flow between medical specialties, nursing teams, health and social care, along with associated administrative and managerial support. A service that has this structure will allow for a more holistic approach to caring for a patient, rather than silo working that is often commonplace." Robertshaw \& Cross, 2017)

Case managers: a point of contact and facilitating access to services

2. Informal carers as equal partners in care provision and decision making
Involving informal carers in decision making for improved care integration
"So that then when it gets to a stage when we really do need help, we've got the confidence in the person (case manager) you've been seeing all along." ( Bamford et al., 2014) "Each service user should be appointed a care coordinator: an [intermediate] who could liaise between service users and service providers." ( Robertshaw \& Cross, 2017)

"You see one person one time and then you'd have, tell them what they need to know and then you see the next person and they don't know, do they. You have to go all through it yeah, you have to start again.” (Bunn et al., 2017) "I went in there and her suitcase was packed and she was going home that day. I found out when I turned up. There was no discussion really." (Bauer et al. 2011) 
Table 4. (continued)

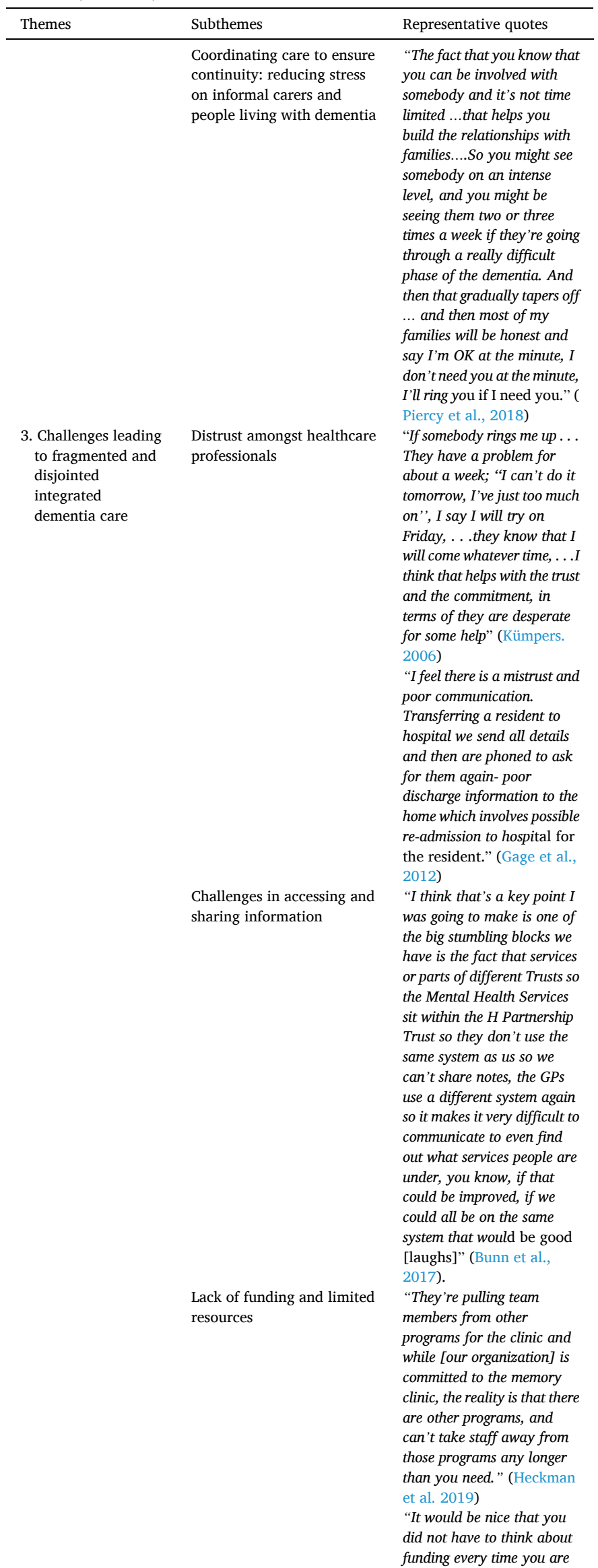

Table 4. (continued)

\begin{tabular}{ll}
\hline Themes & Representative quotes \\
\hline & delivering care. As a \\
professional you should offer & the right care at the right \\
& time in the right place, \\
& independently of the right \\
& funding." (de Lange et al., \\
& 2016) \\
\hline
\end{tabular}

improve client satisfaction. However, evidence exploring the experiences of people living with dementia and their involvement in decisions made about their care appears to be limited. Given previous studies describing integrated care as needing to be person-centred and the ' $p a$ tient's perspective is at the heart of any discussion about integrated care' (Lloyd \& Wait, 2005), exploratory studies with a focus on patient experience should be considered to develop a deeper understanding of what integrated dementia care means to those accessing services. Further, whilst quantitative studies exploring the impact of integrated dementia care interventions have shown some positive results, for example: improvements in memory; quality of life; mental health of the person living with dementia; and reduced carer 'burden' (Ha et al., 2020; Zwingmann et al., 2018), future studies using a mixed-methods approach may provide a more robust understanding of why some interventions work well and others do not.

As most of the studies included in this review were cross-sectional, no inferences can be made surrounding how experiences and perceptions of integrated dementia care change over time. Longitudinal studies which interview all key stakeholder may highlight challenges which occur as the health of person living with dementia declines. For example, how continuity of care is maintained if a person transitions from living independently in the community to residential care. These studies should also seek to explore the experiences of informal carers overtime to examine if and how integrated dementia care affects their levels of stress and perceived caring burden. Informal carers in this review described anxiety and stress related to poor communication from some healthcare professionals, therefore, interventions which target improving informal carer and healthcare professional communication should be considered a priority.

\subsection{Limitations}

Despite a comprehensive literature search, all of the included studies were conducted in western countries with robust health and social care systems. The findings are also skewed to be more relevant to integrated dementia care in the United Kingdom, where 12 of the 23 studies were conducted. It is unclear if these findings will be applicable to developing countries or in cultures where people living with dementia are usually cared for by family members in their own homes with little outside assistance. Where studies included the experiences of people living with dementia and informal carers, ethnicity; religion; and sexuality were rarely described. It is therefore difficult to draw conclusion surrounding whether the findings presented in this review are applicable to those from minority groups.

Only research studies published in English were eligible for inclusion, which could have led to relevant papers being missed. This decision was taken for pragmatic purposes (CRD, 2009), however the findings are therefore biased toward western English-speaking countries. Finally, only the International Journal of Integrated Care was hand searched. This choice was made as it was considered by the research team likely to contain more articles relevant to the research questions, compared to other journals. However, it should be noted that not hand searching other journals in the field of dementia care may have led to relevant papers being missed that were not indexed in the electronic databases. 


\subsection{Future directions}

Future studies should investigate whether there are variations in the perceptions and experiences of integrated dementia care from the perspectives of informal carers and people living with dementia from minority groups. For example, only one study reported ethnicity of informal carer participants (Bunn et al., 2017) and none reported sexual identities. Of the 23 included studies, just three included data from interviews from people living with dementia. It is important future research takes steps to include people living with dementia so that their perceptions and experiences of integrated care can contribute in developing services which they may be using. Further, studies exploring the experiences of those in rural areas, people living with dementia who live alone or without family assistance, and whether there are gender differences in the perceptions of integrated dementia care are needed to help develop policy initiatives to help those who may find it challenging to access integrated dementia care services.

As all included studies were published before 2020, the review findings reflect on experiences in the context of pre-COVID19 dementia care service provision. If and how the current pandemic has impacted on integrated care is currently unknown. Further research to explore if the pandemic has affected integrated dementia care from the experiences of people living with dementia, their families and healthcare professionals is warranted.

\section{Conclusions}

Integrated dementia care can be successful and well received by people living with dementia and their families when certain conditions are met. It relies on effective communication, professional collaboration and the involvement of informal carers in decision making. These can be achieved through employing multidisciplinary teams and case managers to oversee care for people living with dementia over the long term. However, distrust between healthcare professionals, poor interdisciplinary team working, and a lack of resources are barriers which may prevent care integration. Further research is needed to specifically explore the experiences of people living with dementia, their perceptions of integrated care, and whether the COVID-19 pandemic has impacted on integrated dementia care provision. Given the negative consequences fragmented care can have on people living with dementia and their carers, along with the increasing numbers of people being diagnosed with the condition worldwide, action is needed to further support the development of integrated dementia care services.

\section{Acknowledgments}

We would like to thank our funders, the EU Interreg 2 Seas programme, the CASCADE Working Group and our project partners: East Kent Hospitals University NHS Foundation Trust; Emmaus Elderly Care; Flemish Expertise Centre on Dementia; HZ University of Applied Sciences; Medway Community Healthcare; Residential Care Holy Heart; The Health and Europe Centre; University of Lille 3; and ZorgSaam.

\section{References}

Alzheimer Europe (2017). National Dementia Plans: A snapshot of the status of National Dementia Strategies around Europe. www.alzheimer-europe.org/Policy-inPractice2/National-Dementia-Plans (Accessed 22/04/2020).

Armitage, G. D., Suter, E., Oelke, N. D., \& Adair, C. E. (2009). Health systems integration: State of the evidence. International Journal of Integrated Care, 9(e82). https://doi.org/ 10.5334/ijic.316

Bamford, C., Poole, M., Brittain, K., Chew-Graham, C., Fox, C., Iliffe, S., , . . Robinson, L. \& CAREDEM team. (2014). Understanding the challenges to implementing case management for people with dementia in primary care in England: A qualitative study using Normalization Process Theory. BMC Health Services Research, 14, 549. https://doi.org/10.1186/s12913-014-0549-6

Bauer, M., Fitzgerald, L., \& Koch, S. (2011). Hospital discharge as experienced by family carers of people with dementia: A case for quality improvement. Journal for
Healthcare Quality: Official Publication of the National Association for Healthcare Quality, 33(6), 9-16. https://doi.org/10.1111/j.1945-1474.2011.00122.x

Baxter, S., Johnson, M., Chambers, D., Sutton, A., Goyder, E., \& Booth, A. (2018). The effects of integrated care: A systematic review of UK and international evidence. BMC Health Services Research, 18(1), 350. https://doi.org/10.1186/s12913-0183161-3

Booth, A. (2017). Booth A. Qualitative evidence synthesis. In: Facey K. Patient involvement in Health Technology Assessment. Singapore: Springer.

Booth, A., Sutton, A., \& Papaioannou, D. (2016). Systematic Approaches to a Successful Literature Review. London: SAGE.

Bunn, F., Burn, A., Robinson, L., Poole, M., Rait, G., Brayne, C., ... Goodman, C. (2017). Healthcare organisation and delivery for people with dementia and comorbidity: A qualitative study exploring the views of patients, carers and professionals. BMJ Open, 7, Article e013067. https://doi.org/10.1136/bmjopen-2016-013067

Carroll, C., Booth, A., \& Lloyd-Jones, M. (2012). Should we exclude inadequately reported studies from qualitative systematic reviews? An evaluation of sensitivity analyses in two case study reviews. Qualitative Health Research, 22(10), 1425-1434. https://doi.org/10.1177/1049732312452937

Carter, G., Van der Steen, J. T., Galway, K., \& Brazil, K. (2017). General practitioners' perceptions of the barriers and solutions to good quality palliative care in dementia. Dementia: The International Journal of Social Research and Practice, 16(1), 79-95. https://doi.org/10.1177/1471301215581227

Centre for Reviews and Dissemination. (2009). Systematic Reviews: CRD Guidance for Undertaking Reviews in Health Care. CRD: University of York.

Davies, N., Maio, L., Vedavanam, K., Manthorpe, J., Vernooij-Dassen, M., \& Iliffe, S. (2014). Barriers to the provision of high-quality palliative care for people with dementia in England: A qualitative study of professionals' experiences. Health and Social Care in the Community, 22(4), 386-394. https://doi.org/10.1111/hsc.12094

de Lange, J., Deusing, E., van Asch, I. F., Peeters, J., Zwaanswijk, M., Pot, A. M., \& Francke, A. L. (2016). Factors facilitating dementia case management: Results of online focus groups. Dementia, 17(1), 110-125. https://doi.org/10.1177/ 1471301216634959

Department of Health and Social Care. (2013). Integrated Care and Support: Our Shared Commitment - National Collaboration for Integrated Care and Support. Available from https://www.gov.uk/government/publications/integrated-care.

Department of Health. (2009). Living well with dementia: A National Dementia Strategy. London: Crown.

Draper, B., Low, L. F., \& Brodaty, H. (2019). Integrated care for adults with dementia and other cognitive disorders. International Review of Psychiatry, 30(6), 272-291. https:// doi.org/10.1080/09540261.2018.1564021

Gage, H., Dickinson, A., Victor, C., Williams, P., Cheynel, J., Davies, S. L., Goodman, C. (2012). Integrated working between residential care homes and primary care: A survey of care homes in England. BMC Geriatrics, 12, 71. https://doi. org $/ 10.1186 / 1471-2318-12-71$

Goodwin, N. (2016). Understanding integrated care. International Journal of integrated Care, 16(4), 6. https://doi.org/10.5334/ijic.2530

Greenwood, N., Mackenzie, A., Cloud, G. C., \& Wilson, N. (2009). Informal primary carers of stroke survivors living at home-challenges, satisfactions and coping: A systematic review of qualitative studies. Disability and Rehabilitation, 31(5), 337-351. https://doi.org/10.1080/09638280802051721

Ha, N., Yap Lin Kiat, P., Nicholas, S. O., Chan, I., \& Wee, S. L. (2020). Evaluating the outcomes of a hospital-to-community model of integrated care for dementia. Dementia and Geriatric Cognitive Disorders, 49(6), 598-603. https://doi.org/10.1159/ 000512290

Ham, C., \& Curry, N. (2011). Integrated Care: What is it? Does it work? What does it mean for the NHS? London: The King's Fund.

Heckman, GA., Crutchlow, L., Boscart, V., Hillier, L., Franco, B., Lee, L., Molnar, F., Seitz, D., \& Stolee, P. (2019). Quality assurance as a foundational element for an integrated system of dementia care. International Journal of Health Care Quality Assurance, 32(6), 978-990.

Hirakawa, Y., Chiang, C., \& Aoyama, A. (2017). A qualitative study on barriers to achieving high-quality, community-based integrated dementia care. Journal of Rural Medicine, 12(1), 28-32. https://doi.org/10.2185/jrm.2927

Hirakawa, Y., Horie, K., Chiang, C., Shimizu, H., Andoh, H., \& Aoyama, A. (2019). Challenges to successful community-based integrated approach to dementia: A qualitative study. Journal of Gerontological Social Work, 62(6), 613-629. https://doi. org/10.1080/01634372.2019.1640825

Kar, N. (2015). Lack of community care facilities for older people and increased rate of admission and length of stay in hospitals. Journal of Geriatric Care and Research, 2(2), 28-30.

Kosteniuk, J., Morgan, D., Innes, A., Keady, J., Stewart, N., D’Arcy, C., \& Kirk, A. (2014), Who steers the ship? Rural family physicians' views on collaborative care models for patients with dementia. Primary Health Care Research and Development, 15(1), 104-110.

Kümpers, S., Mur, I., Hardy, B., Maarse, H., \& van Raak, A. (2006). The importance of knowledge transfer between specialist and generic services in improving health care: A cross-national study of dementia care in England and The Netherlands. The International Journal of Health Planning and Management, 21(2), 151-167. https://doi. org $/ 10.1002 / \mathrm{hpm} .837$

Kupeli, N., Leavey, G., Harrington, J., Lord, K., King, M., Nazareth, I., Moore, K., Sampson, E. L., \& Jones, L. (2016). What are the barriers to care integration for those at the advanced stages of dementia living in care homes in the UK? Health care professional perspective. Dementia, 17(2), 164-179. https://doi.org/10.1177/ 1471301216636302

Lawn, S., Delany, T., Sweet, L., Battersby, M., \& Skinner, T. (2015). Barriers and enablers to good communication and information-sharing practices in care planning for 
chronic condition management. Australian Journal of Primary Health, 21(1), 84-89. https://doi.org/10.1071/PY13087

Lloyd, J., \& Wait, S. (2005). Integrated Care: A Guide for Policymakers. London: Alliance for Health and the Future.

Low, L. F., \& Fletcher, J. (2015). Models of home care services for persons with dementia: A narrative review. International Psychogeriatrics, 27(10), 1593-1600. https://doi org/10.1017/S1041610215000137

Luckett, T., Chenoweth, L., Phillips, J., Brooks, D., Cook, J., Mitchell, G., ... Agar, M. (2017). A facilitated approach to family case conferencing for people with advanced dementia living in nursing homes: Perceptions of palliative care planning coordinators and other health professionals in the IDEAL study. International psychogeriatrics, 29(10), 1713-1722. https://doi.org/10.1017/S1041610217000977

Minkman, M. M., Ligthart, S. A., \& Huijsman, R. (2009). Integrated dementia care in The Netherlands: A multiple case study of case management programmes. Health and Social Care in the Community, 17(5), 485-494. https://doi.org/10.1111/j.13652524.2009.00850.x

Moher, D., Liberati, A., Tetzlaff, J., \& Altman, D. G. (2009). Preferred reporting items for systematic reviews and meta-analyses: The PRISMA statement. PLoS Medicine, 6(7). https://doi.org/10.1371/journal.pmed.1000097

National Voices. (2013). A Narrative for Person-Centred Coordinated Care. London: National Voices.

Peel, E., \& Harding, R. (2014). It's a huge maze, the system, it's a terrible maze': Dementia carers' constructions of navigating health and social care services. Dementia, 13(5), 642-661. https://doi.org/10.1177/1471301213480514

Piercy, H., Fowler-Davis, S., Dunham, M., \& Cooper, C. (2018). Evaluation of an integrated service delivering post diagnostic care and support for people living with dementia and their families. Health and Social Care in the Community, 26(6), 819-828. https://doi.org/10.1111/hsc.12592

Prince M., Wimo A., Guerchet M., Ali G.C., Wu Y.T., Prina M. (2015). World Alzheimer Report 2015: The Global Impact of Dementia: an analysis of prevalence, incidence, cost and trends. Alzheimer's Disease International. Available online at https://www. alz.co.uk/research/WorldAlzheimerReport2015.pdf.

Risco, E., Cabrera, E., Farré, M., Alvira, C., Miguel, S., \& Zabalegui, A. (2016). Perspectives about health care provision in dementia care in spain: A qualitative study using focus-group methodology. American Journal of Alzheimer's Disease and Other Dementias, 31(3), 223-230. https://doi.org/10.1177/1533317515603818

Robertshaw, D., \& Cross, A. (2017). Experiences of integrated care for dementia from family and carer perspectives: A framework analysis of massive open online course discussion board posts. Dementia, 18(4), 1492-1506. https://doi.org/10.1177/ 1471301217719991

Robertshaw, D., \& Cross, A. (2018). Roles and responsibilities in integrated care for dementia. Journal of Integrated Care, 27(2), 131-140. https://doi.org/10.1108/JICA 05-2018-0037
Robinson, A., Elder, J., Emden, C., Lea, E., Turner, P., \& Vickers, J. (2009). Information pathways into dementia care services family carers have their say. Dementia, 8(1), $17-37$.

Shaw, S., Rosen, R., \& Rumbold, B. (2011). An overview of integrated care in the NHS: What is Integrated Care? London: Nuffield Trust.

Smith, V. M. (2016). Interaction between community pharmacists and community nurses in dementia care. Nursing Older People, 28(3), 33-37. https://doi.org/10.7748/ nop.28.3.33.s 25

Stein, K. V., \& Rieder, A. (2009). Integrated care at the crossroads-defining the way forward. International Journal of integrated Care, 9(e10).

Thomas, J., \& Harden, A. (2008). Methods for the thematic synthesis of qualitative research in systematic reviews. BMC Medical Research Methodology, 8, 45. https:// doi.org/10.1186/1471-2288-8-45

Tong, A., Flemming, K., McInnes, E., Oliver, S., \& Craig, J. (2012). Enhancing transparency in reporting the synthesis of qualitative research: ENTREQ. BMC Medical Research Methodology, 12, 181. https://doi.org/10.1186/1471-2288-12-181

Van Mierlo, L. D., Meiland, F. J., Van Hout, H. P., \& Dröes, R. M. (2014). Towards personalized integrated dementia care: a qualitative study into the implementation of different models of case management. BMC Geriatrics, 14, 84. https://doi.org/ 10.1186/1471-2318-14-84

Vecchio, N., Fitzgerald, J. A., Radford, K., \& Fisher, R. (2016). The association between cognitive impairment and community service use patterns in older people living in Australia. Health \& Social Care in the Community, 24(3), 321-333. https://doi.org/ 10.1111/hsc.12212

Wittenberg, R., Hu, B., Barraza-Araiza, L., \& Rehill, A. (2019). Projections of Older People with Dementia and Costs of Dementia Care in the United Kingdom, 2019-2040. London: Care Policy and Evaluation Centre.

Wolfs, C. A., Kessels, A., Dirksen, C. D., Severens, J. L., \& Verhey, F. R. (2008). Integrated multidisciplinary diagnostic approach for dementia care: Randomised controlled trial. British Journal of Psychiatry, 192(4), 300-305. https://doi.org/10.1192/bjp. bp.107.035204

Woolrych, R., \& Sixsmith, J. (2013). Toward integrated services for dementia: A formal carer perspective. Journal of Integrated Care, 21(4), 208-220.

World Health Organisation [WHO]. (2016). Integrated Care Models: An Overview. Copenhagen: World Health Organisation.

Wright, T., \& O'Connor, S. (2018). Reviewing challenges and gaps in European and global dementia policy. Journal of Public Mental Health, 17(4), 157-167. https://doi. org/10.1108/JPMH-02-2018-0012

Zonneveld, N., Driessen, N., Stüssgen, R., \& Minkman, M. (2018). Values of integrated care: A systematic review. International Journal of Integrated Care, 18(4), 1-12.

Zwingmann, I., Hoffmann, W., Michalowsky, B., Dreier-Wolfgramm, A., Hertel, J., Wucherer, D., ... Thyrian, J. R. (2018). Supporting family dementia caregivers: Testing the efficacy of dementia care management on multifaceted caregivers' burden. Aging \& Mental Health, 22(7), 889-896. https://doi.org/10.1080/ 13607863.2017.1399341 